ISSN 0258-7122 (Print), 2408-8293 (Online)

Bangladesh J. Agril. Res. 43(1): 169-173, March 2018

Short Communication

\title{
MOLECULAR DIVERSITY STUDY IN ADVANCED EARLY MATURING LINES OF RICE USING RAPD TECHNIQUE
}

\author{
H. M. ERSHAD ${ }^{1}$, S. N. BEGUM ${ }^{2}$, M. I. KHALIL ${ }^{3}$ AND M. M. ISLAM ${ }^{4}$
}

Undoubtedly rice (Oryza sativa L.) is the staple food for peoples of many countries. Bangladesh is the fourth largest producer and consumer of rice in the world with annual production about 32 million tones (Anonymous 2014). The global demand of rice will be 880 million tons which is $70 \%$ more than present production in 2025 (IRRI 2010). But production is not increasing accordingly and agricultural lands are decreasing gradually due to intensive and unplanned urbanization. Hence, it is of prime importance for developing short duration and high yielding rice varieties for increasing the cropping intensity purposefully. The knowledge of genetic variability in a given crop species for the characters need to be improvement is important for the success of any plant breeding programme (Bisne et al. 2009). PCR based markers may be used to identify and assess the genetic diversity and phylogenetic relationships in plant genetic resources. Among them RAPD technique is comparatively reliable, faster and easier for exploiting genetic polymorphism within and among species and populations (Shivapriya and Hitalmani 2006). Advantages associated with RAPDs have made them a favorite marker technique in mapping, the determination of phylogenetic relationships, genetic diversity, and identification of cultivars and parents in a number of plant species. RAPD techniques have been successfully used in rice (Rajani et al. 2013; Rahman et al. 2007; Shivapriya and Hitalmani 2006). Thus the present investigation was conducted in order to study the performance of yield and yield contributing characters in early maturing rice genotypes and to determine the variations and also the inherent relationship among the individuals using RAPD marker most successfully.

The youngest healthy leaf samples were collected from the 15-days old seedlings of the rice genotypes. Modified CTAB mini-prep method was followed to extract DNA from leaf samples (Rahman et al. 2007). The concentration of DNA in the samples was determined using a UV Spectrophotometer at $260 \mathrm{~nm}$. The quality of the DNA was verified by electrophoreses on a $0.8 \%$ agarose gel in TBE (Trisboric acid-EDTA) buffer. RAPD amplification reactions were maintained essentially following William et al. (1990) with some modifications. The screening was done with fifteen arbitrary decamer primers (Bengalore Genei, India) using DNA from two cultivars. Three primers resulting scorable and reproducible bands were selected for subsequent RAPD analysis of rice germplasms (Table 1). PCR reactions were performed on each DNA sample in a

\footnotetext{
${ }^{1}$ Department of Biotechnology, Bangladesh Agricultural University (BAU), Mymensingh-2202, ${ }^{2 \& 4}$ Plant Breeding Division, Bangladesh Institute of Nuclear Agriculture, BAU Campus, Mymensingh-2202, ${ }^{3}$ Plant Pathology Division, Bangladesh Institute of Nuclear Agriculture, BAU Campus, Mymensingh-2202, Bangladesh.
} 
$10 \mu 1$ reaction mixture containing $1 \mathrm{x}$ PCR buffer $(10 \mathrm{mM}$ Tris $\mathrm{HCl} \mathrm{pH} 8.5$, $50 \mathrm{mM} \mathrm{KCl}$ and $15 \mathrm{mM} \mathrm{MgCl}_{2}$ ), $10 \mathrm{mM}$ each dNTPs, 5 pmols primer, $2 \mathrm{U}$ of Taq DNA polymerase (Bengalore Genei, India), $100 \mathrm{ng}$ of genomic DNA and rest amount of sterile deionized water. DNA amplification was carried out in a DNA thermocycler (Biometra, Germany) as the following thermal profile: initial denaturation for $3 \mathrm{~min}$ at $94^{\circ} \mathrm{C}$ followed by 41 cycles of 1 min denaturation at $94^{\circ} \mathrm{C}, 1 \mathrm{~min}$ annealing at $35^{\circ} \mathrm{C}$ and extension at $72^{\circ} \mathrm{C}$ for $2 \mathrm{~min}$. A final extension step at $72^{\circ} \mathrm{C}$ for $7 \mathrm{~min}$ was allowed for complete extension of all amplified fragments. The PCR products were kept at $4^{\circ} \mathrm{C}$ until electrophoresis. Reaction mixtures were mixed with $2.0 \mu \mathrm{l} 6 \mathrm{X}$ loading dye. Amplified fragments were separated on a $1.5 \%$ agarose (Bengalore Genei, India) gel in $0.5 \mathrm{X}$ TBE buffer along with $20 \mathrm{bp}$ DNA weight marker (Bengalore Genei, India) for 2 hours at 100V. Gel was stained with Ethidium bromide solution $\left(0.1 \mu \mathrm{g} \mathrm{ml}^{-1}\right)$ for $15 \mathrm{~min}$. Finally fragments were visualized under UV-transilluminator and photographed by Gel Documentation System (Biometra, Germany). The amplified bands were visually scored as present (1) and absent (0) separately for each individual and each primer. The scores obtained were pooled to create a single data matrix, which was used to estimate polymorphic loci, Nei's (1972), genetic diversity, genetic distance and a UPGMA (Unweighted Pair Group Method with Arithmetic Means) dendrogram using a computer program, POPGENE (Version 1.31) (Yeh et al. 1999).

Fifteen primers were initially screened on four genotypes for their ability to produce polymorphic patterns and four primers viz. OPB01, OPB02, OPC01 and OPC05 which gave reproducible and distinct polymorphic amplified products were selected. A total of 36 RAPD bands were scored of which $31(86.24 \%)$ polymorphic amplification products were obtained by using these arbitrary primers. The size of the amplification size ranged from 100-2072 bp (Table 1). The selected four primers produced comparatively the maximum number of high intensity band with minimal smearing, good technical resolution and sufficient variation among different cultivars. The dissimilar numbers of bands were generated by primer OPB01, OPB02, OPC01 and OPC05.

Table 1. RAPD primers with corresponding bands score and their size range together with polymorphic bands observed in four rice genotypes

\begin{tabular}{l|c|c|c|c|c}
\hline $\begin{array}{c}\text { Primer } \\
\text { code }\end{array}$ & $\begin{array}{c}\text { Sequences } \\
\left(5^{\prime}-3^{\prime}\right)\end{array}$ & $\begin{array}{c}\text { Number of } \\
\text { bands } \\
\text { scored }\end{array}$ & $\begin{array}{c}\text { Size } \\
\text { ranged } \\
\text { (bp) }\end{array}$ & $\begin{array}{c}\text { Number of } \\
\text { polymorphic } \\
\text { bands }\end{array}$ & $\begin{array}{c}\text { Polymorphic } \\
\text { loci }(\%)\end{array}$ \\
\hline OPB01 & GTTTCGCTCC & 10 & $100-2072$ & 10 & 100.00 \\
OPB02 & TGCCGAGCTG & 9 & $100-2072$ & 8 & 88.89 \\
OPC01 & TTCGAGCCAG & 11 & $100-2072$ & 8 & 72.73 \\
OPC05 & GATGACCGCC & 6 & $100-2072$ & 5 & 83.33 \\
Total & & 36 & & 31 & 344.95 \\
Average & & 9.0 & & 7.75 & 86.24 \\
\hline
\end{tabular}


Besides, the primer OPB01 amplified the maximum number of polymorphic bands (100\%) while the primer OPC01 generated the least (72.73\%) polymorphic bands which were minimal in number. The banding patterns of four genotypes using primers OPB02 and OPC05 are shown in Figs. 1, and 2, respectively.

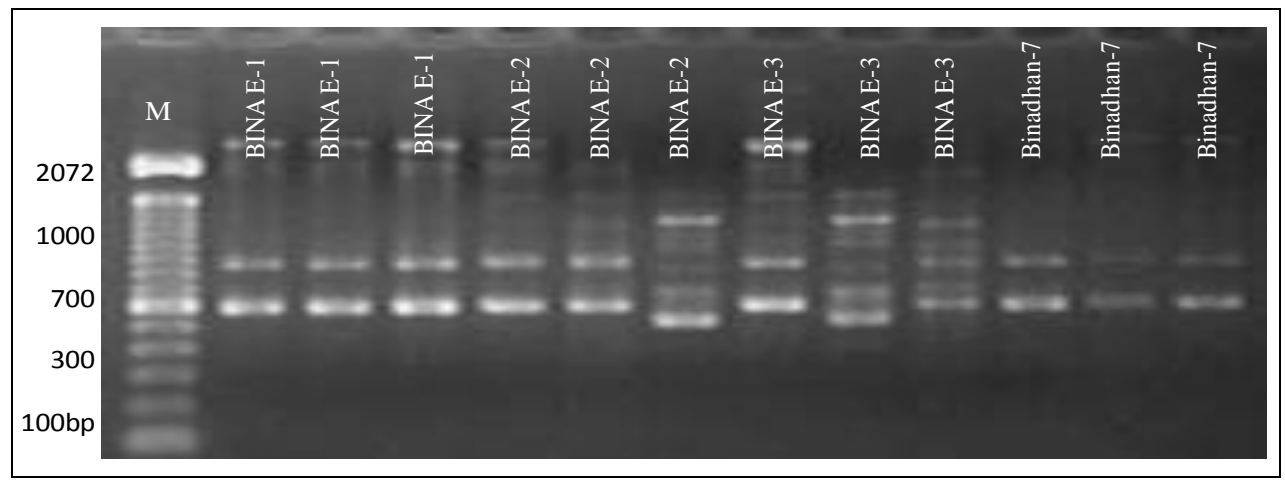

Fig. 2. RAPD profiles of different rice genotypes using primer OPB02. (M): 100 bp ladder

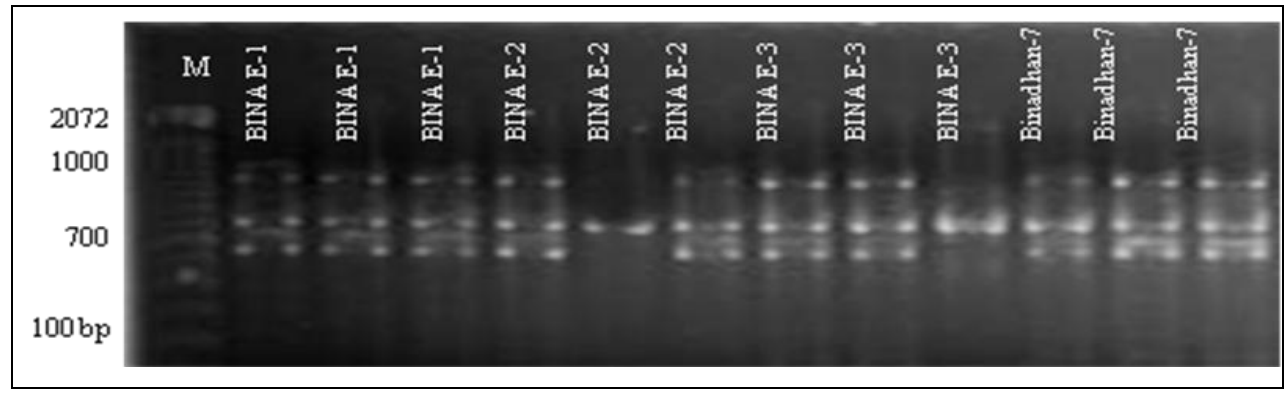

Fig. 4. RAPD profiles of different rice genotypes using primer OPC05. (M): $100 \mathrm{bp}$ DNA ladder

Intra-genotype similarity indices $(\mathrm{Si})$ were higher ranging from 51.07-94.48\% with an average of $73.85 \%$ (Table 2). The highest and lowest intra-genotype similarity indices $\left(\mathrm{S}_{\mathrm{i}}\right)$ value was found in Binadhan-7 and BINA E-3, respectively.

Table 2. Summary of the band sharing based on percentage similarity indices between individuals of four rice genotypes

\begin{tabular}{l|c|c|c|c|c}
\hline \multirow{2}{*}{ Genotypes } & \multicolumn{5}{|c}{ Band sharing values (\%) } \\
\cline { 2 - 6 } & OPB01 & OPB02 & OPC01 & OPC05 & Average \\
\hline BINA E-1 & 100.00 & 92.58 & 83.33 & 100.00 & 93.98 \\
BINA E-2 & 22.22 & 67.95 & 77.78 & 55.55 & 55.88 \\
BINA E-3 & 28.79 & 57.69 & 51.14 & 66.67 & 51.07 \\
Binadhan-7 & 94.87 & 100.00 & 90.47 & 92.58 & 94.48 \\
Average & 61.47 & 79.56 & 75.68 & 78.7 & 73.85 \\
\hline
\end{tabular}


The highest proportion of polymorphic loci $75.00 \%$ was found in BINA-E-3 which gave 27 polymorphic bands and the lowest proportion of polymorphic loci $11.11 \%$ was found in BINA E-1 and Binadhan-7 had four polymorphic bands (Table 3). BINA-E-3 showed the higher level of gene diversity 0.3032 than other genotypes. Gene diversity across all genotypes for all loci was 0.6826 . Binadhan7 showed the lowest 0.0438 gene diversity. Shannon's Information index (I) of all rice genotypes was 0.9932. BINA E-3 and Binadhan-7 showed the highest and lowest 'I' value which were 0.4427 and 0.0643 , respectively (Table 10). Since BINA E-3 exhibited higher percentage of polymorphic loci, gene diversity and Shannon's Information index suggested higher polymorphism.

Table 3. Estimates of genetic variation, Percentage of polymorphic loci. Nei's gene diversity and Shannon's Information index (I) obtained from studied four rice genotypes

\begin{tabular}{l|c|c|c|c}
\hline Genotypes & $\begin{array}{c}\text { No. of } \\
\text { polymorphic loci }\end{array}$ & $\begin{array}{c}\text { Proportion of } \\
\text { polymorphic loci (\%) }\end{array}$ & $\begin{array}{c}\text { Gene } \\
\text { diversity }\end{array}$ & $\begin{array}{c}\text { Shannon's } \\
\text { nformation index } \\
(\mathrm{I})\end{array}$ \\
\hline BINA E-1 & 4 & 11.11 & 0.0542 & 0.0757 \\
BINA E-2 & 25 & 69.44 & 0.2814 & 0.4105 \\
BINA E-3 & 27 & 75.00 & 0.3032 & 0.4427 \\
Binadhan-7 & 4 & 11.11 & 0.0438 & 0.0643 \\
Total & 60 & & 0.6826 & 0.9932 \\
\hline
\end{tabular}

The values of pair-wise comparisons of Nei's (1972) genetic distance among four rice genotypes were computed from combined data sets for the four primers ranging from 0.0554 to 0.9461 (Table 4). Comparatively higher genetic distance was found between BINA E-2 and BINA E-3. The lowest genetic distance was revealed between BINA E-3 and BINA E-2.

Table 4. Summary of Nei's (1972) genetic distance (below diagonal) values among studied four rice genotypes

\begin{tabular}{l|l|l|l|l}
\hline \multicolumn{1}{c}{ Genotypes } & \multicolumn{1}{c}{ BINA E-1 } & \multicolumn{1}{c}{ BINA E-2 } & \multicolumn{1}{c}{ BINA E-3 } & \multicolumn{1}{c}{ Binadhan-7 } \\
\hline BINA E-1 & $* * * *$ & 0.7172 & 0.7879 & 0.8993 \\
BINA E-2 & 0.3324 & $* * * *$ & 0.9461 & 0.6602 \\
BINA E-3 & 0.2383 & 0.0554 & $* * * *$ & 0.7498 \\
Binadhan-7 & 0.1062 & 0.4152 & 0.2880 & $* * * *$ \\
\hline
\end{tabular}

A dendrogram was constructed based on Nei's (1972) genetic distance following the Unweighted Pair Group Method of Arithmetic Means (UPGMA). The four genotypes of rice were grouped into two main clusters (Fig 3). Genotypes BINA E-1 and Binadhan-7 were included in the first cluster while BINA E-2 and BINA E-3 genotypes in the second cluster. Genetic relationship was present between two clusters. Rana et al. (2007) observed similar clustering for the combined data of RAPD and STMS revealed two broad clusters. 


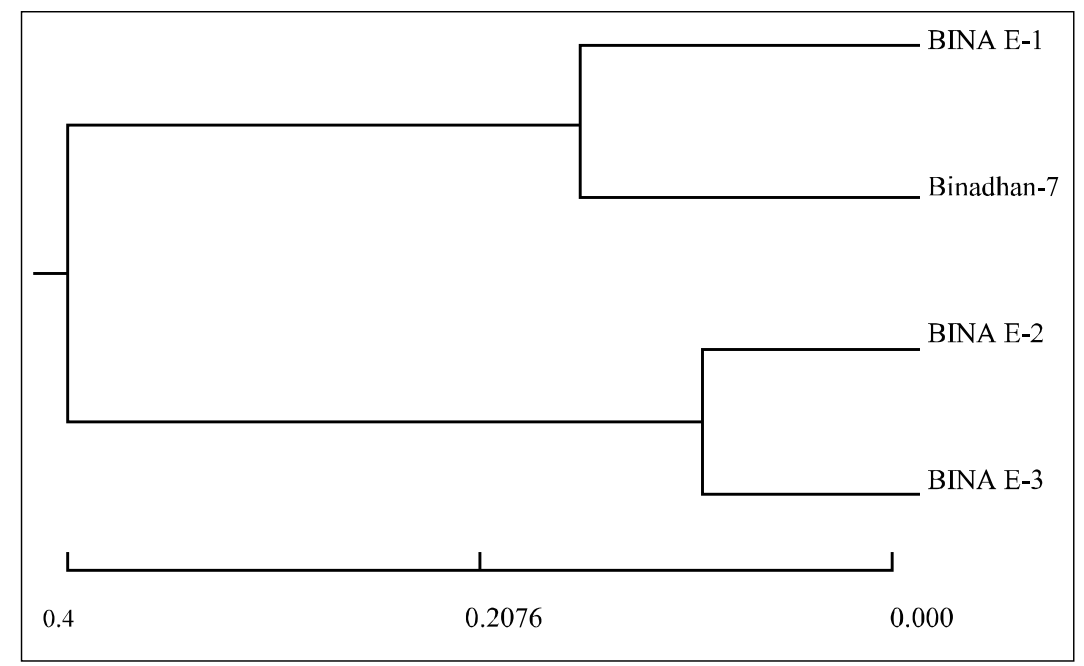

Fig. 3. UPGMA dendrogram based on Nei's (1972) genetic distance summarizing the data on differentiation between 4 rice genotypes, according to RAPD analysis

\section{References}

Anonymous. 2014. Statistical Yearbook of Bangladesh. Bangladesh Bureau of Statistics. Ministry of Planning, Government of the Peoples' republic of Bangladesh. Pp. 244.

Binse R, Sarawgi AK, Verulkar SB. 2009. Study of heritability, genetic advance and variability for yield contributing characters in rice. Bangladesh J. Agril. Res. 34: 175-179.

IRRI (International Rice Research Institute). 2010. Annual Report for 2009. International Rice Research Institute, Los Banos, Laguna, Philippines. Pp. 179-181.

Nei M. 1972. Genetic distance between populations. American Naturalist. 106: 283-292.

Rahman S. N., M. S. Islam, M. S. Alam, K. M. Nasiruddin. 2007. Genetic polymorphism in rice (Oryza sativa L.) through RAPD analysis. Indian J. Biotech. 6(2): 224-229.

Rajani J, V. Deepu, G. M. Nair, A. J. Nair. 2013. Molecular characterization of selected cultivars of rice, Oryza sativa L. using Random Amplified Polymorphic DNA (RAPD) markers. International Food Res. J. 20(2): 919-923.

Rana M. K., K. Ratna, S. Sonika, K. V. Bhat. 2007. Genetic analysis of Indian lentil (Lens culinaris Medikus) cultivars and landraces using RAPD and STMS markers. $J$. Plant Biochem. Biotech. 16(1): 53-57.

Shivapriya M, S. Hitalmani. 2006. Detection of genotype specific fingerprints and molecular diversity of selected Indian locals and landraces of rice (Oryza sativa L.) using DNA markers. Indian J. Genet. Plant Breed. 66(1):1-5.

Williams J. G. K., A. R. Kubelik, K. J. Livak, J. A. Rafalski, S. V. Tingey. 1990. DNA polymorphisms amplified by arbitrary primers are useful as genetic markers. Nucleic Acids Res. 18(22): 6531-6535.

Yeh FC, R. C. Yang, T. B. J. Boyle, Z. H. Ye, J. X. Mao. 1999. POPGENE, the userfriendly shareware for population genetic analysis. Molecular Biology and Biotechnology Centre, University of Alberta, Canada. 
